\title{
ANALISIS KEBUTUHAN PENGEMBANGAN SOAL BERBASIS KEARIFAN LOKAL
}

\author{
Zulfah \\ Universitas Pahlawan Tuanku Tambusai, Jl. Tuanku Tambusai \\ Zulfahasni670@gmail.com
}

\begin{abstract}
Incorporating the elements of culture into the education is still a rare thing. When viewed from mathematics education, almost all the contexts in mathematics are general. In addition, according to Astutik, in his research mentioned that in the process of learning in the classroom, many in the teacher encounter less utilize the environment, especially the local wisdom of local communities in the development of learning tools. The presentation of mathematical problems in the general context of existing teaching materials such as textbooks and LKS is indeed understandable, since Indonesia with its existing cultural richness should not include some cultural elements into the teaching materials provided without giving room for local wisdom others also indicate its existence. The solution that can be taken is to provide a junior mathematics textbook that the book has a local wisdom context of a region. It indicates that it is necessary to develop the existing mathematical problems and relate them to local wisdom. Although the material is presented in a general context, but through the provision of maths based on local wisdom also affects the knowledge and character of learners in the area.
\end{abstract}

Keywords: Analysis Needed, Local wisdom

\begin{abstract}
Abstrak
Memasukkan unsur kebudayaan ke dalam dunia pendidikan masihlah suatu hal yang langka. Jika ditinjau dari pendidikan matematika, hampir semua konteks yang ada di dalam materi matematika bersifat umum. Selain itu, menurut Astutik, dalam penelitiannya menyebutkan bahwa pada proses pembelajaran di kelas, banyak di jumpai guru yang kurang memanfaatkann lingkungan terlebih kearifan lokal masyarakat setempat dalam pengembangan perangkat pembelajarannya. Penyajian soalsoal matematika dalam konteks umum pada bahan ajar yang ada seperti buku paket dan LKS memanglah sesuatu yang dapat dimaklumi, dikarenakan Indonesia dengan kekayaan budaya yang ada tidaklah semestinya memasukkan unsur beberapa budaya saja ke dalam bahan ajar yang disediakan tanpa memberikan ruang untuk kearifan lokal lain juga menunjukkan keberadaannya. Jalan keluar yang dapat diambil adalah dengan menyediakan satu buku soal matematika SMP yangmana buku tersebut memiliki konteks kearifan lokal suatu daerah. Hal tersebut menandakan bahwasanya perlu dilakukan pengembangan terhadap soal-soal matematika yang ada dan mengaitkannya dengan kearifan lokal. Meskipun materi disajikan dalam konteks yang umum, namun melalui pemberian soal matematika berbasis kearifan lokal juga berdampak pada pengetahuan dan karakter peserta didik di daerah tersebut.
\end{abstract}

Kata kunci: Analisis Kebutuhan, Kearifan Lokal, Pengembangan Soal Matematika

Pembelajaran haruslah bermakna bagi peserta didik. Pembelajaran bermakna dapat diperoleh melalui pendekatan dari kehidupan sehari-hari peserta didik. Membahas kehidupan sehari-hari peserta didik berarti membahas kebiasaan yang ada di sekitar peserta didik. Jika pelaksanaan kebiasaan itu merupakan suatu yang bersifat turun temurun, maka hal tersebut dapat dikatakan sebagai sebuah kebudayaan. Salah satu contohnya yaitu ketika ingin pergi sekolah, anak harus 
bersalaman dengan seluruh anggota keluarganya. Jika ini dilaksanakan terus menerus, maka akan menjadi sebuah kebiasaan dan jika dilakukan oleh sebagian besar masyarakat yang ada di sekitar wilayah tersebut, maka itu dapat disebut sebagai sebuah budaya. Jika dilihat dari sisi negatifnya, seseorang yang suka mencontek saja, dapat disebut sebagai budaya, dan tentu saja hal tersebut adalah sesuatu yang harus dihindari dan jangan sampai terjadi yang namanya budaya mencontek.

Pendidikan merupakan salah satu manifestasi kebudayaan. Tujuan pendidikan adalah mengemban tugas luhur untuk mengembangkan peserta didik yang seutuhnya dalam konteks lingkungan alamiah dan kebudayaan yang berkeadaban (Tilaar, 2012: 1136). Artinya, kebudayaan juga dapat disalurkan melalui pendidikan. Salah satu bentuk kebudayaan adalah budaya lokal atau disebut juga dengan kearifan local (Nawang Sulistyani, Sa'dun Akbar 2017).

Kenyataannya, memasukkan unsur kebudayaan ke dalam dunia pendidikan masihlah suatu hal yang langka. Jika ditinjau dari pendidikan matematika, hampir semua konteks yang ada di dalam materi matematika bersifat umum. Selain itu, menurut Astutik, dalam penelitiannya menyebutkan bahwa pada proses pembelajaran di kelas, banyak di jumpai guru yang kurang memanfaatkann lingkungan terlebih kearifan lokal masyarakat setempat dalam pengembangan perangkat pembelajarannya (Astutik 2017). Kurangnya penyisipan atau pemahaman budaya dan tradisi lokal dalam pembelajaran di kelas akan menyebabkan peserta didik kurang menghargai budaya yang ada dan tumbuh di lingkungan sekitar mereka (Astutik 2017).

Padahal dengan mengaitkan materi pelajaran dengan kearifan lokal suatu daerah, akan berdampak pada pengetahuan peserta didik dengan kearifan lokal budayanya. Apalagi ditengah era yangmana moderenitas ataupun "kebarat-baratan "lebih diunggulkan ketimbang budaya, membuat kita sepatutnyalah kembali menumbuhkan kecintaan terhadap kebudayaan atau kearifan lokal daerah. Sekolah juga perlu memiliki dan mendukung pelajaran yang memuat materi berbasis kearifan lokal suatu daerah untuk mencegah hilangnya kearifan lokal suatu daerah (Nawang Sulistyani, Sa'dun Akbar 2017). Kearifan lokal suatu daerah perlu dilestarikan, artinya perlu dijaga dan dilindungi agar tidak punah.

Berbagai upaya telah dilakukan oleh berbagai pihak untuk meningkatkan kualitas pendidikan di Indonesia, seperti melalui penelitian ataupun workshop terkait kearifan lokal. Menghasilkan materi pembelajaran termasuk soal yang berbasis kearifan lokal sangatlah dibutuhkan, sehingga dapat digunakan oleh pihak terkait untuk dijadikan sebagai sumber belajar, ataupun sumber informasi dalam proses pembelajaran (Nawang Sulistyani, Sa'dun Akbar 2017). Anggraini menyatakan bahwa bahan ajar yang mendukung kearifan lokal tidak hanya membekali peserta didik dengan pengetahuan yang kuat tetapi juga karakter yang kuat (Anggraini and Kusniarti 2015).

Fenomena yang dijelaskan sebelumnya perlu untuk dikaji lebih dalam untuk menghasilkan data tentang pengintegrasian kearifan lokal dalam kurikulum pendidikan terutama pada bagian materi pembelajaran. Pengintegrasian tersebut dapat dilakukan untuk meningkatkan kualitas dan 
mutu pendidikan di Indonesia. Selain itu, penelitian ini juga dapat dijadikan sebagai dasar dalam analisis pendahuluan pada pengembangan soal-soal matematika berbasis kearifan lokal. Analisis pendahuluan dilaksanakan untuk memperoleh informasi mengenai permasalahan yang terdapat pada dunia pendidikan. Selain itu melalui analisis pendahuluan, peneliti memperoleh gambaran sementara dari produk yang akan dikembangkan. Pada tahap analisis pendahuluan, dilakukan analisis kebutuhan, analisis peserta didik, analisis kurikulum, analisis konsep, dan analisis bahan ajar yang telah ada (Zulfah 2017b).

\section{METODE PENELITIAN}

Penelitian ini menggunakan penelitian kualitatif. Penelitian kualitatif adalah metode penelitian yang digunakan untuk meneliti pada kondisi objek yang alamiah (Sugiyono, 2014: 1). Pendekatan yang akan digunakan adalah pendekatan deskriptif. Sesuai dengan pendekatan yang digunakan, maka peneliti dijadikan sebagai instrumen utama dalam penelitian. Penelitian ini menggunakan wawancara, observasi, dan dokumentasi dalam mengumpulkan data yang diperlukan. Sumber data diperoleh dari para informan yang dianggap penting seperti guru-guru di daerah Bangkinang sekitar, seperti SMP Negeri 1 Bangkinang, MTs Negeri Sungai Tonang, MTs Negeri Naumbai, SMP Negeri 1 Bangkinang Kota, Bimbel Padjajaran dan Bimbel Ganesa Operation. Sedangkan sumber data sekunder diperoleh melalui studi observasi terhadap pelaksanaan pembelajaran dan dokumentasi berupa soal-soal yang terdapat pada bahan ajar yang digunakan oleh guru pada mata pelajaran matematika di sekolah. Adapun prosedur penelitian yang dilakukan peneliti diilustrasikan pada Gambar 1 berikut(Nawang Sulistyani, Sa'dun Akbar 2017).

- Perencanaan

Tahap

Persiapan

- Membuat pedoman wawancara dan observasi

- Melakukan wawancara dan observasi, dan analisis dokumentasi dengan informan penelitian

Tahap

Pelaksanaan

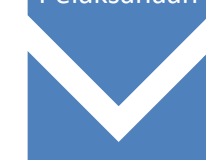

Hasil Temuan

- Menganalisis hasil temuan

- Mengambil kesimpulan

Tahap

- Menyusun Laporan

Gambar 1. Prosedur Penelitian 
Menurut Mile dan Hubberman (1992) teknik analisis data yang digunakan dalam penelitian ini adalah analisis deskriptif, yaitu dengan mendeskripsikan atau menggambarkan data yang telah terkumpul. Setelah data terkumpul dilakukan reduksi data, yang bertujuan memfokuskan data pada hal-hal yang akan diteliti (Zulfah 2017a). Mereduksi data merupakan kegiatan penyederhanaan dan pengabstraksian seluruh data dari hasil observasi, wawancara, dan analisis dokumen berupa soalsoal pada bahan ajar yang digunakan.

\section{HASIL DAN PEMBAHASAN}

Pada tahap pelaksanaan dilaksanakan kegiatan berupa menganalisis bahan ajar matematika SMP, melakukan wawancara, observasi, dan analisis dokumentasi dengan informan penelitian. Berdasarkan pelaksanaan tersebut maka dilaksanakan analisis terhadap data yang diperoleh hasil yang akan dijelaskan selanjutnya.

\section{Hasil Analisis Soal-Soal Pada Bahan Ajar Matematika SMP}

Hasil analisis terhadap bahan ajar matematika kelas VII sampai kelas IX seperti buku paket (E-Book) dan LKS yang digunakan oleh guru tidak ditemukan adanya soal matematika yang dikaitkan dengan kearifan lokal daerah. Soal-soal yang terdapat pada bahan ajar tersebut semuanya bersifat umum. Memang terdapat soal-soal yang dikaitkan dengan kehidupan sehari-hari, namun tidak ada satupun soal yang terkait dengan unsur kearifan lokal suatu daerah. Selain dari buku paket dan LKS yang digunakan guru, hasil observasi dan wawancara yang dilakukan dengan guru matematika juga tidak diperoleh data adanya penggunaan soal-soal matematika berbasis kearifan lokal daerah. Guru memang terbiasa menggunakan soal-soal yang ada di buku paket ataupun LKS. Bahkan di buku kumpulan soal-soal juga tidak ditemukan soal-soal kedaerahan.

Berdasarkan wawancara yang dilakukan, guru tidak pernah terpikir untuk mengembangkan soal-soal-soal berbasis kedaerahan. Sebagian besar guru menganggap bahwa kearifan lokal mungkin dapat diperoleh peserta didik di mata pelajaran yang lain. Selama ini pembelajaran kearifan okal dilakukan secara terpisah dengan pembelajaran umum. Kearifan lokal dapat ditemukan pada muatan lokal seperti arab melayu, budaya melayu riau. Sehingga guru memang tidak memikirkan untuk memasukkan ataupun mencari soal-soal yang berkaitan dengan kearifan lokal.

Secara umum bahan ajar yang digunakan guru masih lebih menekankan kepada aspek pengetahuan. Buku cenderung mengembangkan aspek pengetahuan. Seperti yang juga disampaikan oleh Wurianto (2011) bahwasanya untuk membekali peserta didik menjadi manusia yang berkarakter maka diperlukan pembiasaan positif melalui intranilisasi nilai-nilai karakter terhadap kegiatan pembelajaran yang dilaksanakan.

Berdasarkan analisis tersebut, maka perlu dilakukan pengembangan soal-soal berbasis kearifan lokal yangmana hal tersebut akan memberikan efek positif kepada dunia pendidikan. 
Penyajian soal-soal matematika dalam konteks umum pada bahan ajar yang ada seperti buku paket dan LKS memanglah sesuatu yang dapat dimaklumi, dikarenakan Indonesia dengan kekayaan budaya yang ada tidaklah semestinya memasukkan unsur beberapa budaya saja ke dalam bahan ajar yang disediakan tanpa memberikan ruang untuk kearifan lokal lain juga menunjukkan keberadaannya. Jalan keluar yang dapat diambil adalah dengan menyediakan satu buku soal matematika SMP yangmana buku tersebut memiliki konteks kearifan lokal suatu daerah. Hal tersebut menandakan bahwasanya perlu dilakukan pengembangan terhadap soal-soal matematika yang ada dan mengaitkannya dengan kearifan lokal. Meskipun materi disajikan dalam konteks yang umum, namun melalui pemberian soal matematika berbasis kearifan lokal juga berdampak pada pengetahuan dan karakter peserta didik di daerah tersebut.

\section{KESIMPULAN}

Berdasarkan pada tahap pelaksanaan penelitian dengan mengumpulkan data melalui wawancara, observasi, dan dokumentasi, serta dilakukannya analisis terhadap data yang diperoleh dapat diambil kesimpulan bahwa perlu dilakukan pengembangan terhadap soal-soal matematika berbasis kearifan lokal. Melalui pemberian soal matematika berbasis kearifan lokal dapat memberikan dampak positif kepada peserta didik. Penelitian ini hanya dilakukan untuk menganalisis kebutuhan pengembangan soal matematika. Bagi peneliti lain juga dapat mengembangkan penelitian ini dengan menganalisis kebutuhan pengembangan soal matematika di tingkat sekolah dasar, ataupun tingka sekolah menengah atas, selain itu dapat juga dilakukan penelitian mengenai kebutuhan guru terhadap pengembangan perangkat pembelajaran berbasis kearifan lokal. Melalui penelitian ini, peneliti yang akan melakukan pengembangan baik soal-soal matematika ataupun perangkat pembelajaran dapat dijadikan dasar pada tahap analisis pendahuluan (preliminary research).

\section{DAFTAR PUSTAKA}

Anggraini, Purwati, and Tuti Kusniarti. 2015. "The Insertion of Local Wisdom into Instructional Materials of Bahasa Indonesia for 10 Th Grade Students in Senior High School." Journal of Education and Practice 6(33): 89-92.

Astutik, Endang Poetri. 2017. "Pengembangan Perangkat Pembelajaran Berbasis Kearifan Lokla Masyarakat Usin Banyuwangi Melalui Model Penemuan Terbimbing Pada Pokok Bahasan Trapesium Untuk Meningkatkan Kemampuan Komunikasi Matematika Siswa." Universitas Jember.

Nawang Sulistyani, Sa'dun Akbar, Cholis Sa'dijah. 2017. "ANALISIS KEBUTUHAN PENGEMBANGAN BAHAN AJAR.” In Prosiding TEP Dan PDs, , 836-44.

Zulfah, Zulfah. 2017a. "ANALISIS KESALAHAN PESERTA DIDIK PADA MATERI PERSAMAAN DAN PERTIDAKSAMAAN NILAI MUTLAK LINEAR SATU VARIABEL DI KELAS $X$ SMA NEGERI 1 BANGKINANG KOTA.” Lemma III(2): 1-9. http://ejournal.stkip-pgri-sumbar.ac.id/index.php/jurnal-lemma/article/view/1889. 
2017b. "TAHAP PRELIMINARY RESEARCH PENGEMBANGAN LKPD BERBASIS PBL UNTUK MATERI MATEMATIKA SEMESTER 1 KELAS VIII SMP.” Jurnal Cendekia: Jurnal Pendidikan Matematika 1(2): 1-12. http://journal.stkiptam.ac.id/index.php/cendekia/article/view/184. 